第21回年次大会予稿

\title{
ウィキペディア教育の経験
}

\section{Teaching How to Edit Wikipedia}

\author{
時実象一 ${ }^{1}$ \\ Soichi TOKIZANE ${ }^{1}$
}

1 愛知大学

Aichi University

干441-8522 愛知県豊橋市町畑町 1-1

E-mail: tokizane@aichi-u.ac.jp

図書館情報学志望の学生を対象にウィキペディアの作成実習を行なった. 5-6名のグループ で作成したい記事を選定し，ウィキペディアのアカウントを取得して記事を作成した. 2007 年以降, 25 記事 (うち2記事は既存記事の補足) 作成した. そのうち4記事は削除され，追加記 事のうち2記事は編集を取り消されたが，残りは今も生きている. 実習を受講した学生にアン ケートを実施したところ，「自分でも編集できると知って驚いた」「簡単に編集できるので 驚いた」との感想が合計半数を超えていた. 教員に対するウィキペディアの利用についての アンケート結果についても述べた.

English abstract: In the Library and Information Science class, the Author have students write and edit Wikipedia articles. Groups of 5-6 students each chose an article topic, and created a Wikipedia article with a pre-registered account. Since 2007, 25 articles were created including two edits of existing articles. Among them, four new articles were later removed, and two edits were deleted, but the rest are still alive. A survey of students revealed that many were surprised how easy to edit Wikipedia articles. A survey of teachers about the use of Wikipedia was described, too.

キーワード: ウィキペディア，百科事典，編集，図書館情報学，実習，参考文献

Wikipedia, encyclopedia, editing, library and information science, practice, refrences 


\section{1 背景}

\section{1 ウィキペディアの概要}

ウィキペディアはよく知られているよう に, 参加型の百科事典である. 誰でも新しい 記事を書いたり，他人が書いた記事を編集 できる.

その概要については渡辺の記事 [1] が参 考になる. その仕組みや編集の仕方につい ては，ウィキペディアの管理者のひとりで ある吉沢の著書 [2] が詳しい. また同じく 管理者の日下は，その編集の実態や内容の 信頼性について論じている [3,4]. また山本 ら [5] やアスリーヌら [6] はウィキペディ アの与える社会的影響について論じている. 中でも中村の一連の記事 [7-10] は, ウィキ ペディアの記事を実証的に追跡したものと して一読の価值がある。

前述のようにウィキペディアは多数の参 加者の自治にまかされているが，そこでは 「五本の柱」(表1)，「三大執筆方針」(表2) というガイドラインがある.

表 1 ウィキペディアの五本の柱

のウィキペディアは百科事典です

のウィキペディアは中立的な観点に基づき ます

○ウィキペディアの利用はフリーで、誰でも 編集が可能です

のウィキペディアには行動規範があります

○ウィキペディアには確固としたルールは ありません

なお，記事のスタイルや言葉使いについ ては, 多くの編集者の合意によって決めら れたさまざまなルールがある。
表 2 ウィキペディアの三大執筆方針

中立的な観点

検証可能性

独自研究は載せない

\section{2 先行研究}

ウィキペディアについての最近の論文の 多くは，これを大規模データベース，あるい は言語コーパスとみなして解析したり，才 ントロジー的に利用するといった研究であ り，一般利用者の利用や執筆についての報 告はほとんどない. 長塚ら [11] は学生に対 するアンケートを通じて，学生がじのよう にウィキペディアを理解しているかを報告 している．また執筆サイドでは，土木学会応 用力学委員会のウィキペディアプロジェク トが，ウィキペディアを専門分野の一般社 会での正しい理解を促進するための試みと して注目される [12].

\section{2 ウィキペディア実習教育}

\section{1 概要}

現在ウィキペディアはネット社会で久か すことのできない情報源となっている，し かし，学生によるコピペなど, 安易な使い方 が問題となっていることも事実である. 筆 者は，学生がウィキペディアに対して正し い理解を持つことができるように，その教 育に取り組んできた，そのひとつとして， 2007 年から行ってきた, 学生によるウィキ ペディア編集の実習教育について報告する.

愛知大学文学部の図書館情報学専攻は, わが国では数少ない, 図書館情報学を主題 として掲げる学科である. 専攻への配属は 二年生からで，一年生は希望する専攻につ いて理解を得るための入門講義・入門演習を 
表 3 ウィキペディアの実習テーマ

\begin{tabular}{|c|c|c|c|c|c|c|}
\hline 年 & 記事名 & $\begin{array}{l}\text { 新規 } \\
\text { 追加 }\end{array}$ & 作成日 & $\begin{array}{l}\text { 編集 } \\
\text { 人数 }\end{array}$ & 最新編集日 & 備考 \\
\hline \multirow[t]{3}{*}{2007} & カルミア（豊橋駅ビル） & 新規 & $2007 / 12 / 2$ & 35 & $2012 / 10 / 15$ & \\
\hline & 愛知県立新城東高等学校 & 追加 & $2007 / 11 / 21$ & & & \\
\hline & 名古屋市立当知小学校 & 新規 & & & & 削除 \\
\hline \multirow[t]{3}{*}{2008} & 東刈谷小学校 & 新規 & & & & 削除 \\
\hline & 愛知県立美和高等学校 & 追加 & & & & 取消 \\
\hline & ユナイテッド•シネマ豊橋18 & 新規 & & & & 削除 \\
\hline \multirow[t]{4}{*}{2009} & 豊橋祇園祭 & 新規 & $2009 / 11 / 25$ & 13 & $2013 / 1 / 27$ & \\
\hline & 愛知大学（刊行物） & 追加 & $2009 / 11 / 22$ & & & \\
\hline & 多治見市立平和中学校 & 新規 & $2009 / 11 / 25$ & 9 & $2013 / 4 / 4$ & \\
\hline & 愛知大学（サークル） & 追加 & $2009 / 11 / 25$ & & & 取消 \\
\hline \multirow[t]{5}{*}{2010} & 炭火焼レストランわやか杯 & 新規 & & & & 削除 \\
\hline & 岡崎市立矢作南小学校 & 新規 & $2010 / 12 / 1$ & 7 & $2013 / 3 / 23$ & \\
\hline & 梅田川（愛知県） & 新規 & $2010 / 12 / 1$ & 3 & $2011 / 10 / 8$ & \\
\hline & チョコレートサイダー & 新規 & $2010 / 12 / 1$ & 4 & $2010 / 12 / 26$ & \\
\hline & 豊橋点字図書館 & 新規 & & & & \\
\hline \multirow[t]{5}{*}{2011} & 岡崎市立新香山中学校 & 新規 & $2011 / 11 / 2$ & 5 & $2013 / 3 / 20$ & \\
\hline & あさりせんべい（田原） & 新規 & $2011 / 10 / 26$ & 11 & $2013 / 2 / 1$ & \\
\hline & 高師緑地 & 新規 & $2011 / 11 / 9$ & 4 & $2012 / 8 / 26$ & \\
\hline & 知立まつり & 新規 & $2011 / 11 / 2$ & 8 & $2012 / 4 / 7$ & \\
\hline & おいでん祭（中津川市） & 新規 & $2011 / 10 / 26$ & 3 & $2011 / 11 / 9$ & \\
\hline \multirow[t]{5}{*}{2012} & 霞山文庫 & 新規 & $2012 / 10 / 26$ & 5 & $2012 / 10 / 31$ & \\
\hline & 音楽図書館 & 新規 & $2012 / 10 / 24$ & 4 & $2012 / 11 / 23$ & コメント* \\
\hline & 愛知大学記念館 & 新規 & $2012 / 10 / 24$ & 2 & 2012/12/11 & \\
\hline & 多治見陶器祭り & 新規 & $2012 / 10 / 24$ & 6 & $2013 / 1 / 2$ & \\
\hline & 名護夏祭り & 新規 & $2012 / 10 / 24$ & 2 & $2013 / 3 / 3$ & \\
\hline
\end{tabular}

* ほとんどまたは完全に一つの出典に頼っています.（2012 年 11 月）一次情報源または主題と関係の深い情報源のみに頼って書 かれています. (2012 年 11 月)

受講することとなっている，筆者はこの「入 門演習」を担当しており，そこでは新聞記事 の調査, データベース作成など, 主として情

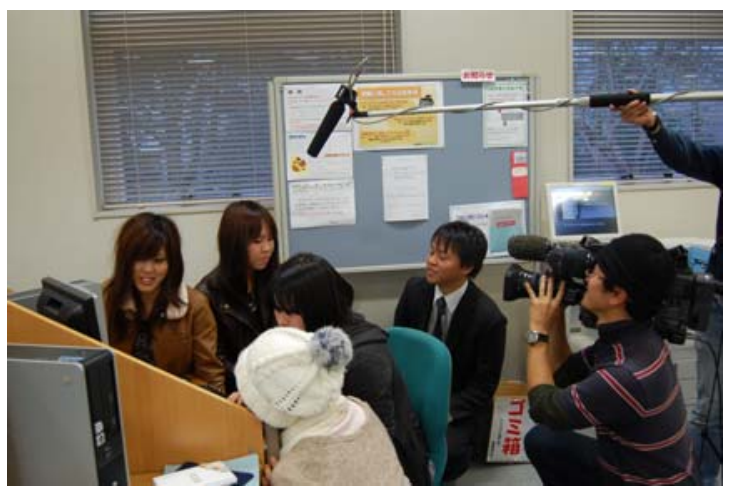

写真 1 NHK の実習授業取材風景
報コンテンツ系の実習をおこなっている。

「入門演習」の実習テーマのひとつとして ウィキペディアの記事を作成・編集すること を始めたのは 2007 年で, 現在まで継続し ておこなっている、そこで作成・編集した記 事は表3のとおりである.

この取組みは外部でも注目され, 2009 年 11 月 25 日の NHK「ニュースウォッチ9」 で取材・放映された (写真1).

\section{2 実習の進め方}

\subsection{1 記事の選定}

学生は数名でグループとなり, 各グルー 
プで作成したい記事を選定した. 選択した テーマは，自分はよく知っているが，まだ記 事となっていないもの，たとえば，地域の施 設や行事，出身学校，図書館情報に関するテ 一マ,などを推奨した. トラブルになりやす いテーマ，たとえば，タレント，アニメ，時 事問題などに関するものは避けることとし た.

その結果，一部削除された記事もあるが， ほとんどが現在も生きている.

\subsection{2 記事の準備}

まず Word などで記事原稿を作成し, 教 員がチェックした. ウィキペディアは著作 権の侵害防止には極めて厳格であるため, 既存サイトからの文章のコピペは禁止した。 またそのジャンルのテンプレート (たとえ ば「高等学校」) があれば，それを利用し，類 似の記事があれば，そのスタイルにならっ た.

\subsection{3 記事の作成}

ウィキペディアはユーザ登録しなくても 執筆・編集が可能である。この実習を開始し た当初は, 非登録ユーザとして編集をおこ なったが，後述のようなトラブルが発生し たため, その後は必ずアカウントを登録し てから編集することとした。

記事に写真を入れる場合は，一旦ウィキ メディアに登録する必要があるため, 教員 がアップロードした。

作成して一週間程度経て削除されない場 合は，ほとんどの場合その後も安定して掲 載されている.

\section{3 問題点}

\subsubsection{IP アドレスブロック}

2007/2008 年には, アカウントを取得しな いで，直接編集をおこなった，その場合は， 編集履歴に大学の IP アドレスが残る. 編集 が特定の日に集中したため，「荒らし」とみ なされ, 作成した記事が削除された上, 大学 の IP アドレスがブロックされた (2008年 12月).これについては担当管理者に事情を 説明し，ブロックを解除してもらった。

\section{3 .2 未熟な記述}

当初は教員も慣れておらず，指導も不十 分だったので, 学生が, 検証が困難な, ある いは事典にふさわしくない記述をおこなう ようなことがあった.たとえば，ある高等学 校の記事において,

「3年に一度くらい, 近隣の高校の生徒 により, xx 高校の生徒を対象とした「xx 狩り」と称される暴力行為が行われ

る.」

との記述をした例があった。これは教員が 気づいて削除した。

\subsection{3 記事の削除}

ウィキペディアにおける記事の削除方針 では, (1) 法的問題がある場合 (著作権また はプライバシー), (2) ページ名に問題がある 場合, (3) 百科事典的でない記事, (4) 投稿 者本人から依頼がある場合，などかあげら れている [13]. 作成した記事のうち，「名古 屋市立当知小学校」,「東刚谷小学校」,「工 ナイテッド・シネマ豊橋18」,「炭火焼レス トランさわやか杯」はその後削除されてい る.

ウィキペディアでは, 記事内の記述の編 集や削除は履歴で確認できるが, 記事その ものが削除された場合は，追跡が困難であ り，削除の理由は明らかでない.おそらくは， 
(1) 記事が短すぎて内容がない, (2) 該当施 設または行事がマイナーで事典に掲載する 価值がない，というような判断ではなかつ たかと推測している.

\section{3 教育の効果}

\section{1 アンケート調査}

実習をおこなった学生に,アンケート調 査を実施した。結果は図 1-6 のとおりであ る.

自由記入項目において, 役に立った記事 としては,「ドラマの登場人物」,「タレン 卜に情報」,「ゲームの攻略」など, 趣味系

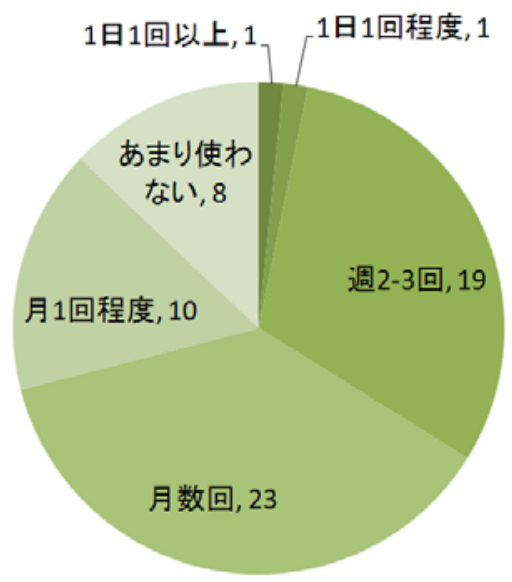

図 1 ウィキペディアの使用頻度

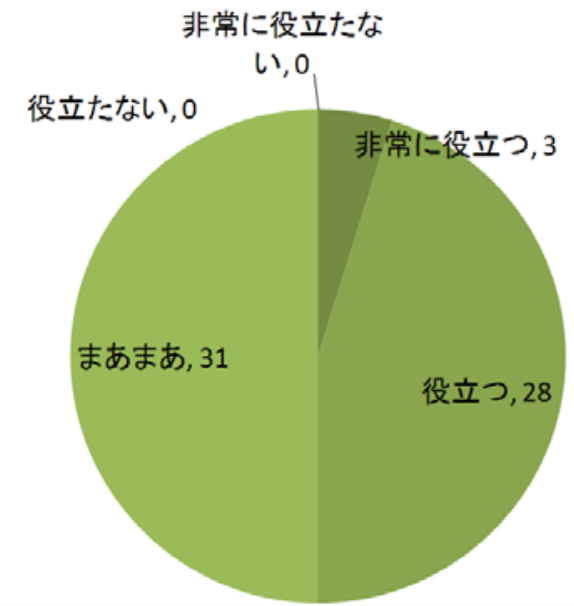

図 3 ウィキペディアの有用性
の記事が目立った．また品質が気になった 記事としては，「歴史上の人物」，「芸能人」， 「時事問題」などが挙げられていた。

\section{4 ウィキペディアからの引用}

\section{1 コピペ}

ウィキペディアからのコピペはこれまで もしばしば問題となっている (Middlebury 大学事件 [14], 国際建設技術協会事件 [15], 議員海外視察事件 [16]). 大学現場でもウィ キペディアを含むネットからのコピペは問 題となっている. 当大学の教員にアンケー

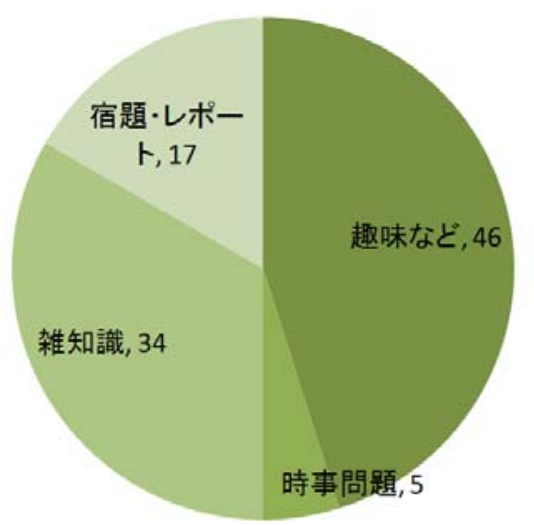

図 2 ウィキペディアの使用目的

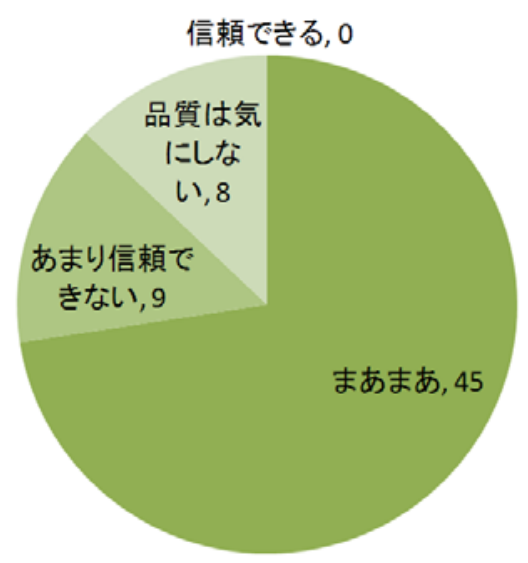

図 4 ウィキペディアの信頼性 


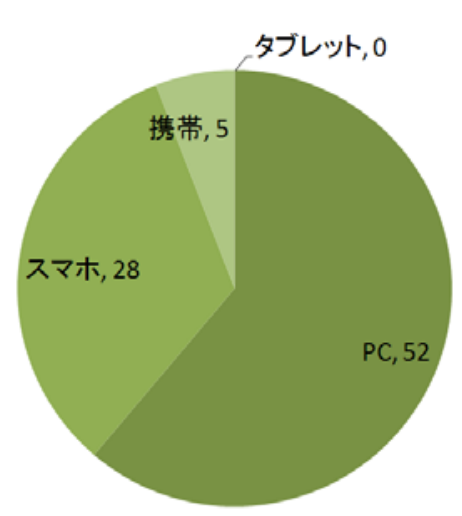

図 5 ウィキペディアの有用性

卜をとったところ, 表 1 のような事例があ った (2008 年 7 月). 最近は深刻な事例は 耳にしていないが，文章単位のマイナーな コピペは相当数に登ると思われる.

\section{2 引用}

一方でウィキペディアの記事を参考文献 として引用することについては賛否がある. 前述の当大学のアンケートでも, A. ウィキ

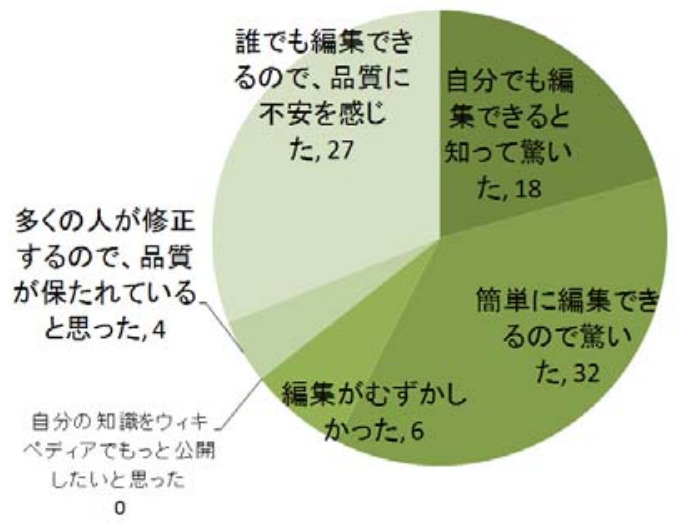

図 6 ウィキペディアの信頼性

表 1 愛知大学教員が経験したコピペの例 (2008/7)

\begin{tabular}{|c|c|}
\hline 1 & コピペに使われた URL あり. \\
\hline 2 & 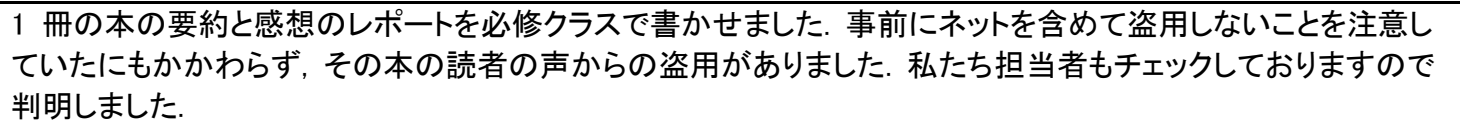 \\
\hline 3 & $\begin{array}{l}\text { 「盗用」について考える (判断) がわずらわしいので, 盗用しにくい具体例を中心としたしポート，あるいは筆記 } \\
\text { 試験にかえた. }\end{array}$ \\
\hline 4 & 新書の紹介と感想文のゼミでの発表時 \\
\hline 5 & 卒論の中に解説書からの文末を替えただけけの引き写しがあった (10 年前). \\
\hline 6 & $\begin{array}{l}\text { しポートの中にインターネットのホームページ (個人) からのコピペがあった }(2 \text { 年前). 以後その科目は定期試 } \\
\text { 験によって評価している. レポートでの評価は受講生との間に信頼関係がなければ可能." }\end{array}$ \\
\hline 7 & 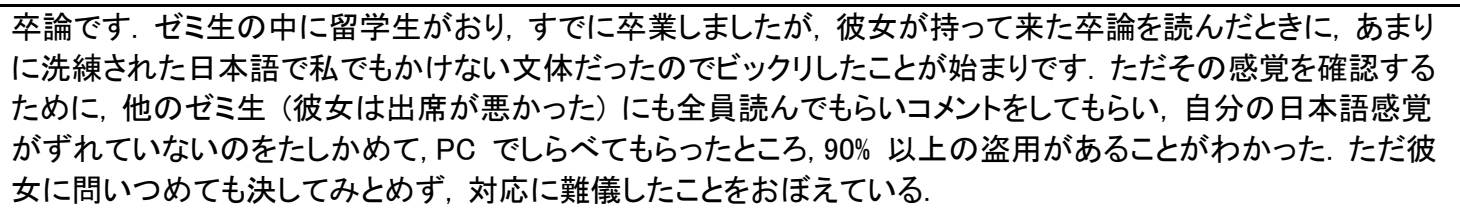 \\
\hline 8 & $\begin{array}{l}\text { ゼミレポート, 講義レポートは盗用ができない課題を出しますから, 友人のレポートを書き写して, 少し修正して } \\
\text { 出すというくらいの盗用しか今のところりません. }\end{array}$ \\
\hline 9 & Wikipedia の内容をそのまま (英文) レポートに. \\
\hline
\end{tabular}


いる [17]. 筆者は，これらの理由に加え， そもそも, ウィキペディアに限らず匿名の 著作物を引用することには批判的である [18, 19]. この問題はさらに議論が必要であ ろう。

\section{5 おわりに}

本実習授業の実施にあたっていろいろ助 言をいただき, また本稿についても助言を 頂いた，ウィキペディア管理者の日下九八 氏に感謝いたします。ささらにアンケート調 査にご協力いただいた, 本学教員の方々, 本 学山本昭准教授および学生の方々に感謝い たします。

\section{参考文献}

[1] 渡辺智暁. われわれはウィキペディアと どうつきあうべきか：メディア・リテラシ 一の視点から. 情報の科学と技術. 2011, 61(2), 64-69.

[2] 吉沢英明.「Wikipedia 完全活用ガイド」. マックス, 2006. 12. 31, 95 pp.

[3] 日下九八. ウィキペディア：その信頼性 と社会的役割. 情報管理. 2012, 55(1),

481-488.

[4] 日下九八.ウィキペディアの基本的な編 集方法と考え方 間違いを正しく編集する . 情報管理. 2012, 55(7), 481-488.

[5] 山本 まさき, 古田 雄介. 「ウィキペデ イアで何が起こっているのか一変わり始め るソーシャルメディア信仰」.九天社. 2008, $228 \mathrm{p}$.

[6] ピエール・アスリーヌ, 他. 「ウィキペ ディア革命 そこで何が起きているのか」.岩 波書店. 2008.
[7] 中村 英.「ウィキペディアは「Web 2.0」 の旗手たり得るか (1): 危うい「権威の一人 歩き」。朝日総研リポート, 2007. 3, (202), 17-31.

[8] 中村 英.「ウィキペディアは「Web 2.0」 の旗手たり得るか (2): 信頼性を保つため に」. 朝日総研リポート, 2007. 4, (203), 88-101.

[9] 中村 英.「ウィキペディアは「Web 2.0」 の旗手たり得るか (3): 創設者ウェールズが 語る軌跡と将来」. 朝日総研リポート, 2007. 5, (204), 92-103.

[10] 中村 英. 「ウィキペディアは「Web 2.0」の旗手たり得るか (4): バージニア工科 大学銃乱射事件が教えるもの」. 朝日総研リ ポート, 2007. 6, (205), 46-60.

[11]長塚隆，神野こずえ。学生における Wikipedia 日本語版の利用動向.情報知識学 会誌. 2011, 21(2), 149-156.

[12] 山川優樹 柴田俊文, 中井健太郎. 専門 知識の発信による学会の社会貢献 : 土木学 会応用力学委員会のウィキペディアプロジ エクト.情報管理. 2013, 55(11), 819-825.

[13] Wikipedia:削除の方針.

http://ja.wikipedia.org/wiki/Wikipedia:\%E5\%89 \%8А\%Е9\%99\%А4\%Е3\%81\%AE\%Е6\%96\%B9 \%E9\%87\%9D (閲覧 2013/4/19).

[14] A History Department Bans Citing Wikipedia as a Research Source. The New York Times. 2007/2/21.

[15] 風知草:「たった 3 冊で 1 億円」事件. 毎 日新聞 2008/3/10. 東京朝刊.

[16] [著作権問題]:ネット発コピペ文化, 政界 も侵食中. 2007/03/30.

http:/gendaiforum.typepad.jp/news/2007/03/30/ (閲覧 2013/4/11).

[17] 大学レポート・論文の書き方. レポート 
とWikipedia（ウィキペディア）.

http://www.report.gusoku.net/kihon/wikipedia.ht ml (閲覧 2013/4/11).

[18] 時実象一.「私の視点: ウィキペディア

－安易な引用はやめよう」。朝日新聞 (東京
本社版). 2007./7/24, 朝刊.

[19] 時実象一.「ウィキペディアがめざす知 識革命，その光と陰」.月刊公明. 2008 (5), 56-62. 